\title{
Twobandad Japanese Weevil, Pseudocneorhinus bifasciatus Roelofs (Insecta: Coleoptera: Curculionidae) ${ }^{1}$
}

Jamba Gyeltshen and Amanda Hodges ${ }^{2}$

\section{Introduction}

The twobanded Japanese weevil, Pseudocneorhinus bifasciatus (Roelofs), first collected in the United States in 1914 near Philadelphia, was most likely introduced with infested nursery stock from Japan (Wheeler and Boyd 2005). With a host range of over 100 plant species, the twobanded Japanese weevil is recognized in the northeastern and midwestern United States as an important pest of landscape plantings (Wheeler and Boyd 2005). Although not a pest of major concern yet in the southeastern states, it is likely to extend its range due to movement of nursery stock. In July 2005, two specimens of the twobanded Japanese weevil were collected at Chipley, Florida, which is in Washington county (Thomas 2005).

\section{Synonymy}

Pseudocneorhinus bifasciatus Roelofs

Callirhopalus bifasciatus (Roelofs)

Pseudocneorhinus setosus of authors, not Roelofs

\section{Distribution}

The twobanded Japanese weevil is native to China, Japan, Korea, Mongolia, and eastern Siberia (Wheeler and Boyd 2005). It is now established in the eastern United States, and occurs in New England, the mid-Atlantic states, Indiana, and Illinois (Wheeler and Boyd 2005). Its distribution in the southeastern United States was studied by Wheeler and Boyd (2005) who reported that the weevil was first collected Alabama in 1970, Georgia in 1959, North Carolina in 1955, and South Carolina in 1966.

Its presence in Florida was confirmed in July 2005 (Thomas 2005). It must be noted, however, that the order of detection may not reflect the order of establishment because of the lack of knowledge of the time lag between establishment and detection (Wheeler and Boyd 2005). As the weevil is flightless, it is unlikely to spread to long distances by jumping, and a pattern of dispersal in this manner is not evident in the mapped records of the southeastern region (Wheeler and Boyd 2005). Therefore the spread in the southeastern states is possibly due to the movement of infested ornamental plants.

1. This document is EENY-361 (IN646), one of a series of Featured Creatures from the Entomology and Nematology Department, Florida Cooperative Extension Service, Institute of Food and Agricultural Sciences, University of Florida. Published: December 2005. This document is also available on Featured Creatures Website at http://creatures.ifas.ufl.edu. Please visit the EDIS Website at http://edis.ifas.ufl.edu. 2. Jamba Gyeltshen and Amanda Hodges, Department of Entomology and Nematology, University of Florida, Gainesville, FL.

The Institute of Food and Agricultural Sciences (IFAS) is an Equal Opportunity Institution authorized to provide research, educational information and other services only to individuals and institutions that function with non-discrimination with respect to race, creed, color, religion, age, disability, sex, sexual orientation, marital status, national origin, political opinions or affiliations. U.S. Department of Agriculture, Cooperative Extension Service, University of Florida, IFAS, Florida A. \& M. University Cooperative Extension Program, and Boards of County Commissioners Cooperating. Larry Arrington, Dean 


\section{Description}

Adult: The adult twobanded Japanese weevil is stout, convex, and pear-shaped with a short, blunt snout, and elytra much broader than the pronotum. It is about $5 \mathrm{~mm}$ long, and has a body covered with brown and grey scales that form bands across the elytra (Thomas 2005). The elytra are fused and due to lack of flight wings, the adult weevils cannot fly. The weevils feed during the day but are less apparent because of their subdued brown coloration and markings (Smith 1955).

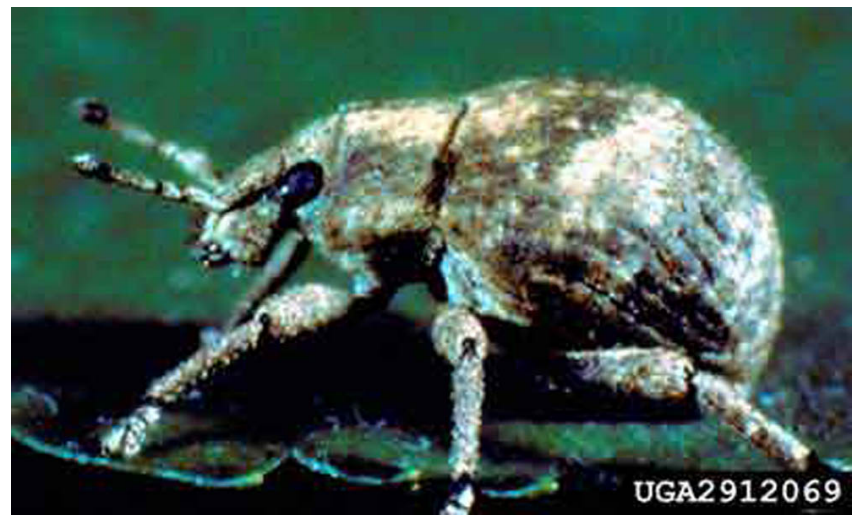

Figure 1. Adult twobanded Japanese weevil, Pseudocneorhinus bifasciatus (Roelofs). Credits: Dr. James R Baker, Professor Emeritus, North Carolina State University

Immatures: A variable number of small, cream colored eggs are laid within egg pods formed on leaf margins. Egg pods are formed by adult females folding the leaf margin and pressing the edges with their legs (Zepp 1978).

Larva and pupa of $P$. bifasciatus have been described by Marrone and Zepp (1979). Fully-grown larvae are white, legless, and 7.5 to $8.5 \mathrm{~mm} \mathrm{(} \mathrm{3/10}$ inch) long. The pupa is white with yellow-brown setae, and is $6.25 \mathrm{~mm}$ long.

\section{Biology}

Twobanded Japanese weevils reproduce parthenogenetically, and males are generally not encountered in the United States although they are known to occur in China (Wheeler and Boyd 2005). The following detail of the biology and lifecycle of the twobanded Japanese weevil is based on a study by Allen (1959) under the northeastern climate. The

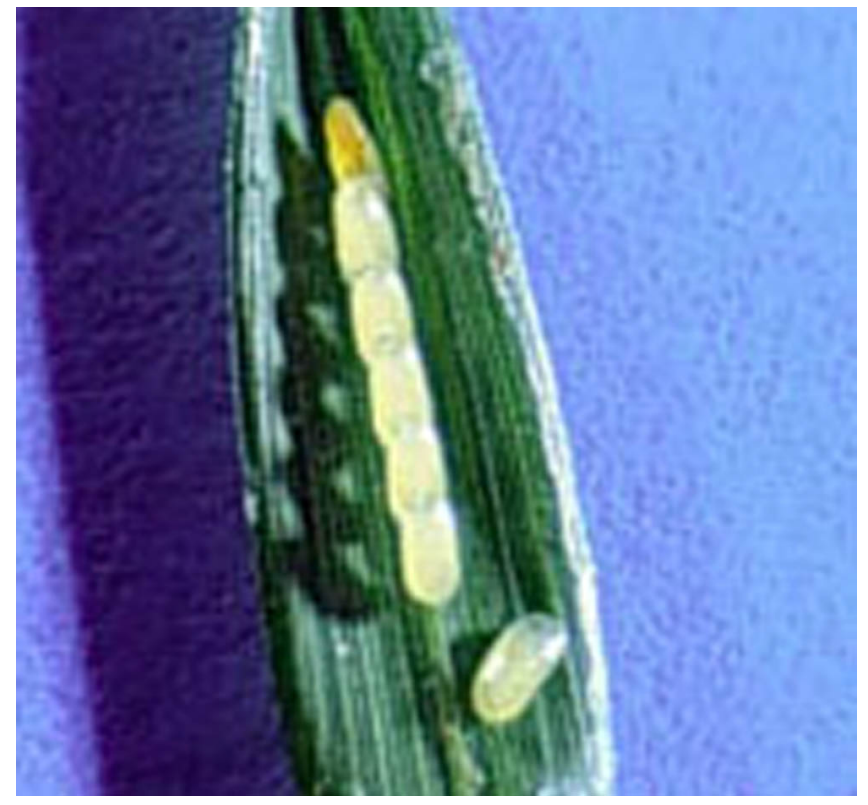

Figure 2. Eggs of twobanded Japanese weevil, Pseudocneorhinus bifasciatus (Roelofs), on grass blade that had been glued together by the adult female. Credits: Dr. James R Baker, Professor Emeritus, North Carolina State University

duration of life cycle and seasonal activity may vary in the southeastern region but has not been reported.

In the northeastern United States, twobanded Japanese weevils overwinter as adult, egg or larva, and has one generation per year (univoltine). With the approach of the warm weather in spring, the overwintering population of adult weevils become active and resume feeding. Eggs are laid from middle of May through October. The peak period for oviposition is from September to early October, and oviposition stops by November.

Eggs are deposited within the leaf-folds along the margins, the free edges of which are sealed to form a 'pod.' The egg pods bear a series of depressions along the margins, which are marks left by the clamping action of the tibia (Zepp 1978). Twobanded Japanese weevils are known to oviposit in freshly fallen leaves or on leaf fragments dropped as a result of feeding. An egg pod contains one to nine eggs with an average of 2.6 eggs (Allen 1959) or five eggs (Zepp 1978). Adult fecundity appears to be influenced by the type of foliar diet. For example, under laboratory conditions, adults on a foliage diet of multiflora rose, Rosa multiflora (Thunb.) had a 
fecundity of about 355 eggs as compared to seven eggs on mountain laurel, Kalmia latifolia (Maer 1983).

Eggs hatch in 14 to 18 days. The newly hatched larvae drop to the ground and burrow into the soil to feed on the roots. Larval activity is generally limited to the soil under the canopy of the adult-infested host plant. Allen (1959) encountered as high as 150 larvae per square feet in the soil samples taken from underneath the canopies of heavily infested privet (Ligustrum) hedges. Larvae were found at depths ranging from one to nine inches but were more concentrated between three and six inches below the surface.

Not much is known about the larval development in the soil, except the observation by Allen (1959) that by early May some larvae of the previous midsummer brood undergo pupation. Adults emerge from late June to early July and eventually outnumber the overwintering population. The combined population cause extensive damage to foliage. By the middle of October, the weevils are not observed on the host plant and are most likely hibernating. They hibernate in debris under infested plants.

\section{Host Plants}

Twobanded Japanese weevils are known to feed on over 100 species of plants (Boyd and Wheeler 2004). Despite an extremely broad host range, their limited presence on a number of known hosts suggests that host suitability for feeding, egg development and egg laying may vary substantially (Maier 1983). In a field sampling to discover the relative abundance of different species of weevils on various hosts, Maier (1986) obtained higher number of catches on multiflora rose (Rosa multiflora).

Other hosts recorded by Marrone and Zepp (1979) include azalea (Rhododendron), privet (Ligustrum), Forsythia, Abelia, Viburnum, Acer, Morus, Populus, Sedum, Lythrum, Campsis, Thunbergia, and Coleus. Twobanded Japanese weevils are especially found in cherry laurel (Prunus laurocerasus), Pyracantha, Euonymus, barberry (Barberis) (Day 2003). Other hosts include ash (Fraxinus), burr marigold (Bidens), Camellia, dogwood (Cornus), elm (Ulmus), fern, hemlock (Tsuga), holly (Ilex), lilac (Syringa), mountain laurel (Kalmia latifolia), rose (Rosa), Spirea, strawberry (Fragaria), Weigela, Koelreuteria, and Deutzia.

\section{Damage}

Both adults and larvae cause plant damage. Adults cause defoliation, whereas the larvae live in the soil and destroy the roots. Adults chew leaf tissues at the margins and create notches. Initial damage by the overwintering population of adults is quickly masked by rapidly growing spring flushes, but severe defoliation can occur when new adults emerge. Past records show that twobanded Japanese weevils are capable of stripping privet (Ligustrum) hedges, 50 feet in length, and can cause irreparable damage to hemlocks (Britton 1932). Typically, twobanded Japanese weevils are noticed only when large population cause extensive defoliation.

\section{Management}

The twobanded Japanese weevils can be collected and destroyed if infestations are not extensive. They feed during the day, and when disturbed, quickly drop to the ground and remain still or feign death (Baker 1994). This behavior makes it convenient to collect them by tapping or shaking the plant. A white sheet of cloth or paper could be laid out under the shrub to catch them as they drop (Baker 1994).

Chemical control recommendations against the twobanded Japanese weevils for Florida are not available. However, extension recommendations are available from other states that have populations of this weevil (Day 2003, Baker 1994). The best timing for insecticide sprays is when the overwintering adults resume their feeding activity in spring, i.e. when the first signs of leaf damage are observed. Close monitoring for the first signs of foliar damage is therefore important for management.

\section{Selected References}

- Allen HW. 1959. The Japanese weevil Pseudocneorhinus bifasciatus Roelofs. Journal of Economic Entomology 52: 586-587. 
- Boyd Jr DW, Wheeler Jr AG. (2004). In Oliver J. (Section Editor), Entomology Section. SNA Research Conference, Vol. 49. http://www.sna. org/research/04proceedings/04proceedingspdfs/ ResProcSec03.pdf (6 October 2005).

- Baker JR. (1994). Twobanded Japanese weevil. Ornamentals and Turf: Department of Entomology Insect Note. NC Cooperative Extension Service, North Carolina State University. http://www.ces.ncsu.edu/depts/ent/ notes/O\&T/shrubs/note34/note34.html (6 October 2005).

- Britton WE. 1932. Scientific Notes: Injury by Japanese weevil, Pseudocneorhinus setosus Roelofs. Journal of Economic Entomology 25: 931.

- Day ER. (2003). Japanese Weevil Coleoptera: Curculionidae, Pseudocneorhinus bifasciatus. Virginia Cooperative Extension, Entomology, Publication 444-624. http://www.ext.vt.edu/ pubs/entomology/444-624/444-624.html (6 October 2005).

- Maier CT. 1983. Influence of host plants on the reproductive success of the parthenogenetic twobanded Japanese weevil, Callirhopalus bifasciatus (Roelofs) (Coleoptera: Curculionidae). Environmental Entomology 12: 1197-1203.

- Maier CT. 1986. Relative abundance of adults of Callirhopalus bifasciatus (Roelofs) and three Otiorhynchus spp. (Coleoptera: Curculionidae). Journal of the New York Entomological Society 94: 70-77.

- Marrone PG, Zepp DB. 1979. Descriptions of the larva and pupa of Callirhopalus (subg. Pseudocneorhinus) bifasciatus, the twobanded Japanese weevil, with new host plant records. Annals of the Entomological Society of America 72: 833-836.

- Smith FF. 1955. Scientific Notes: Notes on the biology and control of Pseudocneorhinus bifasciatus. Journal of Economic Entomology 48:628-629.
- Thomas MC. (2005). Pest Alert: The twobanded Japanese weevil (Pseudocneorhinus bifasciatus Roelofs), an invasive pest new to Florida (Coleoptera: Curculionidae). http:// www.doacs.state.fl.us/pi/enpp/ento/ japaneseweevil.html (24 August 2005).

- Wheeler AG, Boyd Jr DW. 2005. Southeastern U.S. distribution of an invasive weevil, Pseudocneorhinus bifasciatus Roelofs (Coleoptera: Curculionidae). Journal of Entomological Science 40: 25-30.

- Zepp DB. 1978. Egg pod formation by Callirhopalus (subg. Pseudocneorhinus) bifasciatus (Roelofs) (Coleoptera: Curculionidae: Eremninae). Coleopterists Bulletin 32: 311-313. 